\title{
Environmental Assessment of Enzyme Production and Purification
}

\author{
Martin Becker, Stephan Lütz (D) and Katrin Rosenthal *(D) \\ Chair for Bioprocess Engineering, Department of Biochemical and Chemical Engineering, \\ TU Dortmund University, D-44227 Dortmund, Germany; martin4.becker@tu-dortmund.de (M.B.); \\ stephan.luetz@tu-dortmund.de (S.L.) \\ * Correspondence: katrin.rosenthal@tu-dortmund.de; Tel.: +49-231-755-5115
}

\section{check for}

updates

Citation: Becker, M.; Lütz, S.; Rosenthal, K. Environmental Assessment of Enzyme Production and Purification. Molecules 2021, 26, 573. https://doi.org/10.3390/ molecules 26030573

Academic Editor: Cesar Mateo Received: 30 December 2020

Accepted: 19 January 2021

Published: 22 January 2021

Publisher's Note: MDPI stays neutral with regard to jurisdictional claims in published maps and institutional affiliations.

Copyright: (c) 2021 by the authors. Licensee MDPI, Basel, Switzerland. This article is an open access article distributed under the terms and conditions of the Creative Commons Attribution (CC BY) license (https:/ / creativecommons.org/licenses/by/ $4.0 /)$.

\begin{abstract}
The importance of bioprocesses has increased in recent decades, as they are considered to be more sustainable than chemical processes in many cases. $E$ factors can be used to assess the sustainability of processes. However, it is noticeable that the contribution of enzyme synthesis and purification is mostly neglected. We, therefore, determined the $E$ factors for the production and purification of $10 \mathrm{~g}$ enzymes. The calculated complete $E$ factor including required waste and water is $37,835 \mathrm{~g}_{\text {waste }} \cdot \mathrm{g}_{\text {enzyme }}{ }^{-1}$. This result demonstrates that the contribution of enzyme production and purification should not be neglected for sustainability assessment of bioprocesses.
\end{abstract}

Keywords: E factor; biocatalysis; green chemistry; cGAS; bioprocess engineering; life cycle assessment

\section{Introduction}

In 2002, at least 134 bioprocesses had been applied at an industrial scale with the largest proportion in the pharmaceutical sector [1]. Since then, the use of enzymes for the production of valuable products, especially in the pharmaceutical industry, has continued to increase. Nowadays, enzymes have received much attention regarding their potential to enable catalysis with a high substrate specificity, regio- and stereoselectivity under mild conditions. Biocatalysts hold hence a vast potential for many synthesis applications and are interesting for sustainable syntheses. A prominent industrial example is the manufacturing process for the antihyperglycemic drug sitagliptin, which represents the potential of chemoenzymatic reactions to reduce the environmental impact in the pharmaceutical industry [2].

The sustainability of a process can be assessed in different ways. The environmental impact of an entire process is considered with a life cycle assessment (LCA), which includes the entire life cycle of a product from the fabrication of raw materials to production, use and final disposal [3]. However, the preparation of an LCA can be extremely labor-intensive and requires specific expertise, if basic data on the materials used are not available in the standard databases. An LCA, therefore, serves less as a standard calculation in researchoriented groups to quickly and easily assess the environmental impact for a process under development [4]. In addition, common LCA substance databases are still designed for the assessment of chemical processes and many compounds relevant in bioprocesses are currently not available [5].

Due to the complexity of an LCA, simpler mass-based metrics are required in order to evaluate the efficiency and sustainability of a process. For this purpose, the pharmaceutical industry, prefers the use of Process Mass Intensity (PMI), which is the ratio of the mass of all used chemicals to the mass of isolated product (see Appendix A Equation (A1)) [6]. In an ideal process, the PMI is 1 . Another frequently used value to assess the environmental impact of syntheses is the $E$ factor established by Roger Sheldon [7]. The $E$ factor indicates the ratio between the amount of waste generated during the production of a certain amount of product (see Appendix A Equation (A2)). It was expanded by including the energy consumed during production and referred to as $E^{+}$factor (see Appendix A Equation (A3)) [8] The disadvantage of these mass-based metrics is that they do not consider the different 
hazards and toxicities of the waste streams. The advantage, on the other hand, is that they are easy to calculate and thus allow a quick assessment of the sustainability of a process.

The calculation of these $E$ factors have already been carried out for various bioprocesses $[9,10]$. However, the production and purification of the biocatalyst is often not considered for the sustainability assessment [4], although, it is expected that the enzyme manufacturing has a significant contribution to the overall assessment. For this reason, we calculated the chemicals, water, and energy consumptions required for the expression and purification of a model enzyme. We selected the human nucleotidyltransferase cyclic GMP-AMP synthase (cGAS) for this purpose, as one of the standard enzymes in our lab. cGAS serves as a DNA sensor in the cytosol [11]. It catalyzes the synthesis of cyclic GMP-AMP (cGAMP), which is currently of great interest in cancer immunotherapy or as adjuvant to vaccines due to the properties to induce the release of type 1 interferons in the nucleus [12-14]. Based on this reference enzyme, the process was designed for the production and purification of $10 \mathrm{~g}$ enzyme and $E$ factors were calculated. The results of these calculations demonstrate that the biocatalyst synthesis represents a significant ecological contribution to bioprocesses that should not be neglected.

\section{Results}

Biocatalysis is generally considered as green chemistry with attractive features: mild reaction conditions, environmentally friendly catalysts, water as solvent combined with high activity, selectivity and specificity and thereby generating less waste. However, it is rarely stated how much waste, energy, and water is actually needed to produce the biocatalyst. In this study, the chemicals and energy required for enzyme production were calculated. The specific requirements are that the enzyme should be available in isolated, purified form and thus be suitable for the synthesis of valuable substances and active ingredients. The following process steps were therefore considered: Expression, cell harvesting, cell disruption and enzyme purification.

The process was designed for an enzyme quantity of $10 \mathrm{~g}$, which is sufficient to synthesize 10 to $1000 \mathrm{~g}$ of product corresponding to the amount required for e.g., preclinical or phase 1 clinical studies $[15,16]$. As reference the recently reported enzyme cGAS was chosen, which has proven to be a promising biocatalyst for the synthesis of cyclic dinucleotides due to its promiscuous properties $[17,18]$. Cyclic dinucleotides might act as stimulator of interferon genes (STING) agonist and are therefore pursued as strategy for cancer therapy [13]. As shown in Figure 1, $250 \mathrm{~g}$ of cGAMP can be synthesized with an enzyme quantity of $10 \mathrm{~g}, 228 \mathrm{~g}$ ATP and $235 \mathrm{~g}$ GTP as educts, as well as chemicals for the reaction buffer.
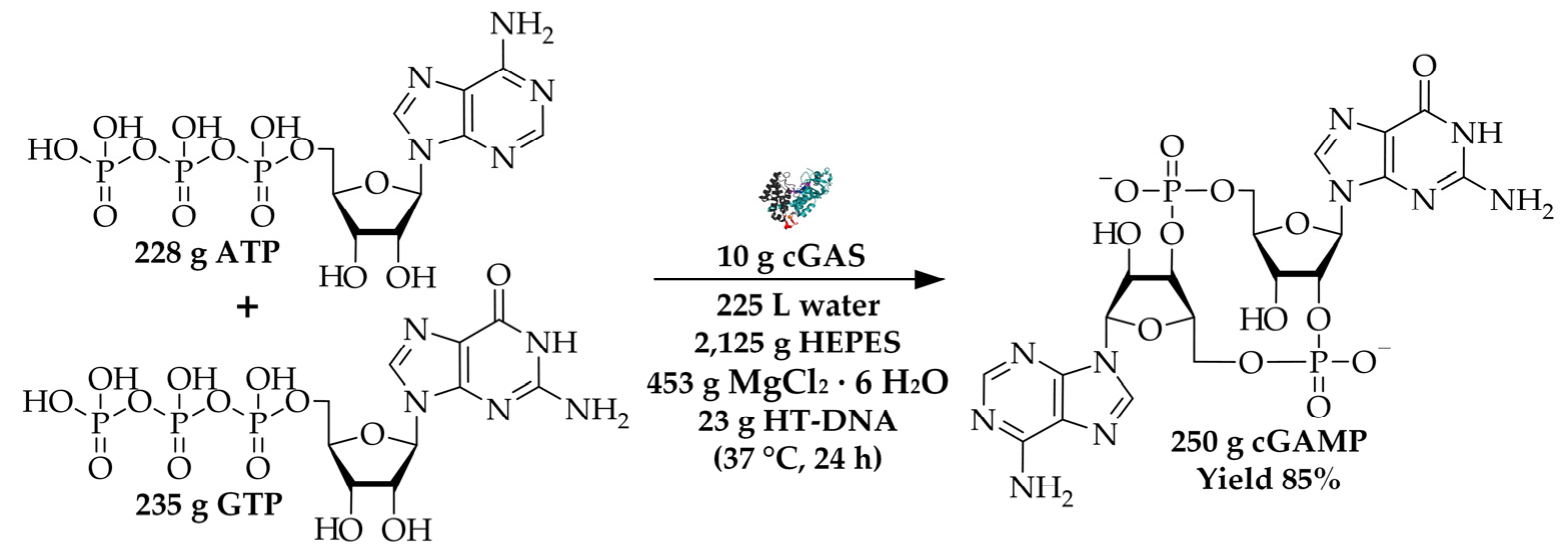

Figure 1. Overview of cGAMP synthesis with $10 \mathrm{~g}$ cGAS. The reaction is performed in a reaction volume of $225 \mathrm{~L}$ containing $40 \mathrm{mM}$ 4-(2-hydroxyethyl)-1-piperazineethanesulfonic acid (HEPES) buffer, $10 \mathrm{mM} \mathrm{MgCl} 2 \cdot 6 \mathrm{H}_{2} \mathrm{O}$ and $23 \mathrm{~g}$ herring testes DNA (HT-DNA) for the activation of the enzyme. 
To obtain reference values, the model enzyme cGAS was synthesized in E. coli BL21 (DE3) pLysS in 2xYT (yeast extract tryptone) medium in a shaking flask, whereby a cell dry weight (CDW) of $1.73 \mathrm{~g} \cdot \mathrm{L}^{-1}$ was achieved. An average protein yield of $21.35 \pm 2.55 \mathrm{mg}_{\mathrm{cGAS}} \mathrm{gCDW}^{-1}$ was purified. The obtained value was assumed for the following calculations, as it seems to be reasonable in comparison to published values $[19,20]$. The estimation of the maximum cell concentration should rather be regarded as too low, since higher cell concentrations are to be expected especially in controlled bioreactor systems [4]. Additionally, switching from nutrient-rich to defined minimal media can also lead to higher cell concentrations [21]. Nevertheless, the obtained cell concentration is used for further calculations in order to keep the calculations of the achievable concentrations under known fermentation conditions close to reality.

Based on these initial values, the required unit operations were selected and dimensioned, which are summarized in Figure 2. A detailed overview of the individual process steps can be found in the Supplementary Materials. The size of the main fermenter for enzyme synthesis was estimated to $275 \mathrm{~L}$ for a production of $468 \mathrm{~g}$ CDW. The seed train for inoculation of the main fermenter consists of a $3 \mathrm{~L}$ and $30 \mathrm{~L}$ bioreactor. The pre-cultivations for biomass production are carried out at $37^{\circ} \mathrm{C}$ for $14 \mathrm{~h}$. The expression follows in the main fermenter at $20^{\circ} \mathrm{C}$ for $11 \mathrm{~h}$, after a short biomass production phase of $3 \mathrm{~h}$ at $37^{\circ} \mathrm{C}$.

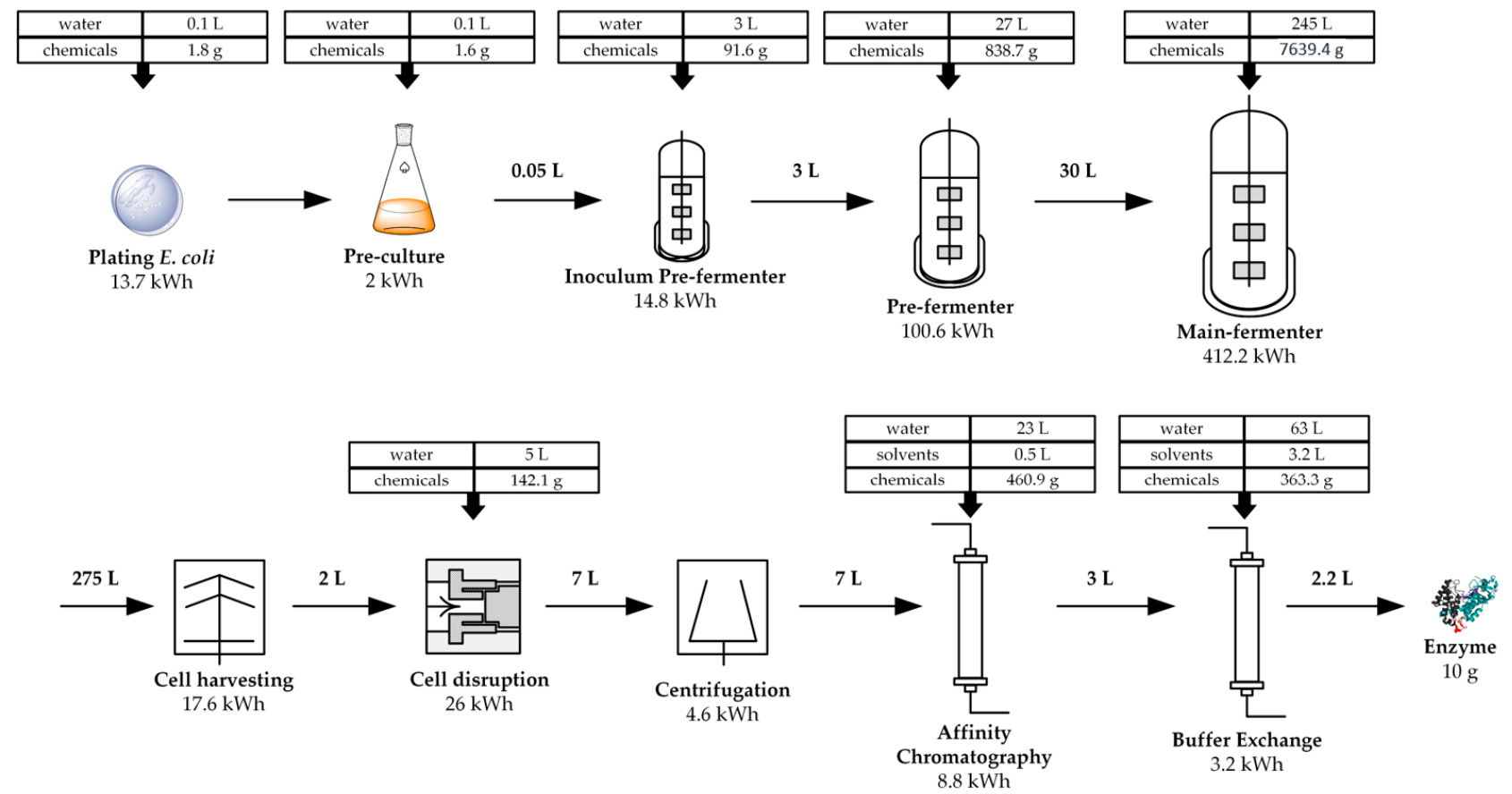

Figure 2. Overview of the unit operations required for the production and purification of $10 \mathrm{~g}$ enzyme. After cultivation of the E. coli BL21 (DE3) LysS expression strain on an agar plate, cultivation follows in a shaking flask and two pre-fermenters. After synthesis of the desired enzyme cGAS in the main-fermenter, the cells are harvested using a disk separator. The cells are disrupted using a high-pressure homogenizer and insoluble cell components are removed by centrifugation. The enzyme is purified by affinity chromatography and buffer exchange. The required amount of chemicals, water, and energy are specified for each unit operation.

Cells are subsequently harvested with a plate separator with an estimated volume flow of $100 \mathrm{~L} \cdot \mathrm{h}^{-1}$, resuspended in $5 \mathrm{~L}$ lysis buffer and disrupted using a high-pressure homogenizer. Insoluble cell debris is separated by centrifugation at 10,500 rpm for $20 \mathrm{~min}$ at $4{ }^{\circ} \mathrm{C}$. The enzyme is then isolated from the cell extract solution by $\mathrm{His}_{6}$-tag affinity chromatography. For this purpose, the Ni Sepharose ${ }^{\mathrm{TM}} 6$ Fast Flow resin was selected, which can bind $40 \mathrm{mg}$ enzyme $\cdot \mathrm{mL}^{-1}$ resin and was also used for the laboratory scale experiments. Since a complete loading of the resin seems unrealistic from our own experience, the calculated column volume was increased from $250 \mathrm{~mL}$ to $500 \mathrm{~mL}$ resin for $10 \mathrm{~g}$ enzymes. Based 
on this column volume, the consumption of all other chemicals was estimated according to the manual of the resin. Since imidazole is used for elution, which could have a negative influence on the enzyme stability, it is removed in the last step by gel filtration. For this purpose, the Sephadex G-25 resin was selected, which was also used for the laboratory scale experiments. A required column volume of $5.25 \mathrm{~L}$ was estimated. Finally, $10 \mathrm{~g}$ enzyme in 2.2 L HEPES buffer is obtained. The chemicals required for the production of $10 \mathrm{~g}$ enzyme are summarized in Table 1.

Table 1. List of all chemicals required for the production and purification of $10 \mathrm{~g}$ enzyme. For this purpose, the model enzyme cGAS was synthesized in E. coli BL21 (DE3) pLysS in 2xYT (yeast extract trypton) medium and subsequently purified by cell disruption, centrifugation, affinity chromatography, and buffer exchange.

\begin{tabular}{|c|c|}
\hline Chemicals & {$[g]$} \\
\hline Tryptone & 4401 \\
\hline Yeast Extract & 2750 \\
\hline $\mathrm{NaCl}$ & 1687 \\
\hline Agar & 2 \\
\hline Kanamycin & 14 \\
\hline Chloramphenicol & 3 \\
\hline $\mathrm{IPTG}^{1}$ & 29 \\
\hline Imidazole & 153 \\
\hline $\mathrm{TCEP}^{2}$ & 2 \\
\hline Tris- $\mathrm{HCl}$ & 136 \\
\hline HEPES $^{3}$ & 174 \\
\hline $\mathrm{MgCl}_{2} \cdot 6 \mathrm{H}_{2} \mathrm{O}$ & 37 \\
\hline Ethanol & 2919 \\
\hline Water & 366,150 \\
\hline
\end{tabular}
piperazineethanesulfonic acid.

In total, $9.39 \mathrm{~kg}$ of chemicals, $2.92 \mathrm{~kg}$ of solvent and $367.25 \mathrm{~L}$ of water are necessary to produce $10 \mathrm{~g}$ of cGAS. It should also be mentioned that for industrial production typically minimal media without complex components like tryptone are used. Water and chemicals required for the subsequent cleaning of all devices were not considered in the calculations. This also applies to the cooling water of the bioreactors. Figure 3 illustrates the calculated amount of chemicals and water consumption required for seed-train, protein expression and purification.

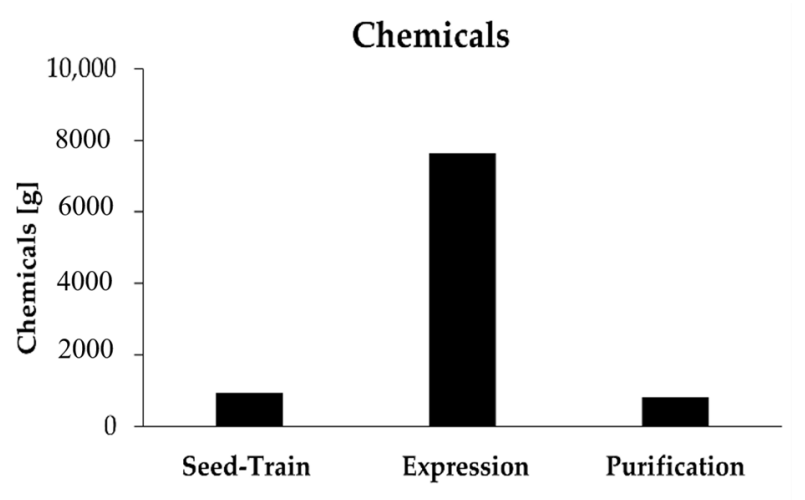

(a)

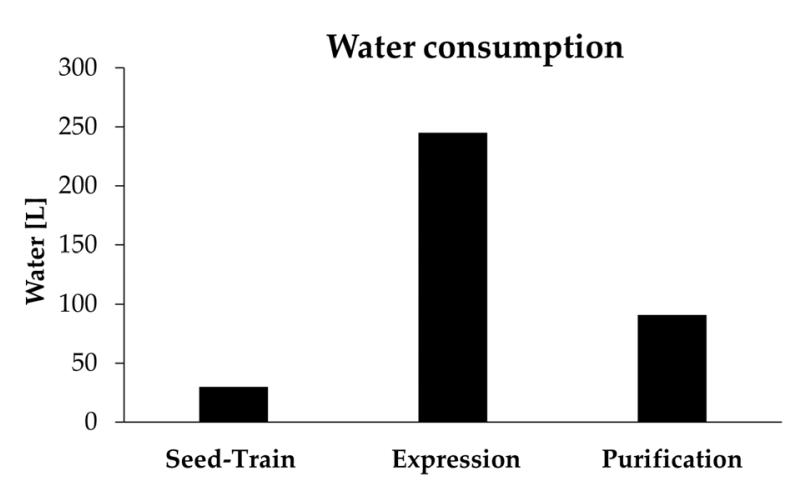

(b)

Figure 3. Consumption of chemicals and water for the production and purification of $10 \mathrm{~g}$ of enzyme: (a) amount of chemicals [g] for protein expression and purification; $(\mathbf{b})$ water consumption [L] for protein expression and purification. 
It is shown that large amounts of chemicals and water consumption are especially deducted for the expression. About $7.64 \mathrm{~kg}$ of chemicals and $245 \mathrm{~L}$ of water are required for the expression. The seed-train has a chemical consumption of $0.93 \mathrm{~kg}$ and a water consumption of $30 \mathrm{~L}$. For protein purification, only $0.81 \mathrm{~kg}$ of chemicals and $91 \mathrm{~L}$ of water are used. Therefore, the expression step represents the greatest potential for savings. Water consumption could be reduced by achieving higher cell densities during fermentation resulting in smaller reactor volumes. In high cell density fermentations, cell densities of up to $50 \mathrm{~g} \mathrm{CDW} \cdot \mathrm{L}^{-1}$ can be achieved, which significantly exceeds the cell concentration of $1.73 \mathrm{~g}_{\mathrm{CDW}} \cdot \mathrm{L}^{-1}$ in this study [4]. As already mentioned, the obtained protein yield of $21.35 \mathrm{mg}_{\text {enzyme }} \cdot \mathrm{g}_{\mathrm{CDW}}{ }^{-1}$ is in a usual range for E. coli BL21 (DE3) pLysS. Nevertheless, higher values have also been obtained with a lactose fed-batch expression of the acylcarrier protein $\Delta^{9}$ desaturase in E. coli BL21 (DE3). Yields of $66 \mathrm{mg}_{\text {enzyme }} \cdot \mathrm{g}_{\mathrm{CDW}}{ }^{-1}$ were achieved after purification with two ion exchange chromatography steps and subsequent ultrafiltration [22]. These results show that higher protein yields can be obtained, although the increase in maximum cell density during expression certainly has the greater effect.

In addition to the amount of chemicals and water, the energy required for the individual process steps was calculated (Tables A1 and A2). For the bioreactors, sterilization and motor power for stirring are the main energy consuming contributions [23] and were therefore considered for calculation. For the other process steps, the amount of energy was estimated based on the energy consumption of the used devices. In total, an energy consumption of $603.46 \mathrm{kWh}$ was calculated. The sterilization of waste streams was neglected in the calculation. Likewise, the amounts of energy required for cooling and heating of the bioreactors were not taken into account.

Figure 4 shows the required energy for protein expression and purification. The protein expression with an energy consumption of $412.2 \mathrm{kWh}$ is the most energy-intensive step compared to seed-train or purification. These process steps require only 131 and $60 \mathrm{kWh}$. The energy consumption could be significantly reduced by increasing cell density and enzyme yields and thereby decreasing the reactor volume. With a ten-fold increase in cell concentration during expression, the overall energy consumption would be reduced to approximately $200 \mathrm{kWh}$.

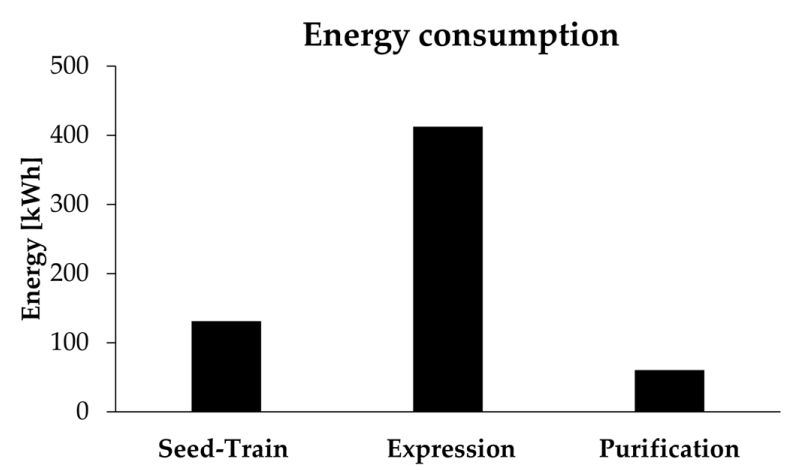

Figure 4. Energy consumption for the production of $10 \mathrm{~g}$ of enzyme during seed-train, protein expression and purification.

Assuming a $\mathrm{CO}_{2}$ emission of $401 \mathrm{~g}_{\mathrm{CO} 2} \cdot \mathrm{kWh}^{-1}$ in Germany in 2019 [24], a $\mathrm{CO}_{2}$ emission of $242 \mathrm{~kg}$ was calculated for the production and purification of $10 \mathrm{~g}$ enzyme. Based on the thus calculated amounts of chemicals, water and solvent consumption as well as the energy consumption and $\mathrm{CO}_{2}$ emission, the simple $E$ factor, complete $E$ factor and $E^{+}$factor (Appendix A Equations (A2) and (A3)) were calculated (Table 2).

The simple $E$ factor is $938 \mathrm{~g}$ waste per g cGAS and includes only the chemicals needed to produce one gram of enzyme. Additionally, the $E$ factor does not include the environmental impact and toxicity of this waste. When assessing the toxicity of the waste streams, TCEP, imidazole as well as the antibiotics kanamycin and chloramphenicol should be noted in particular. These chemicals are corrosive, harmful and irritant. In total, 
however, these critical compounds contribute only $17.2 \mathrm{~g}$ of the $938 \mathrm{~g}$ of waste per $\mathrm{g}$ of cGAS indicating that the quantities are comparatively low.

Table 2. Calculated $E$ factors for the production and purification of cGAS. The $E$ factors for the enzymes rAaeUPO, which was expressed with Pichia pastoris, and AoFOx, which was expressed in $E$. coli at lab scale (13 L bioreactor), are also listed as a reference [8]. The simple $E$ factor includes the used chemicals. The complete $E$ factor additionally considers water required for the production and purification. The $E^{+}$factor also includes the $\mathrm{CO}_{2}$ emissions caused by the energy consumption during production.

\begin{tabular}{cccc}
\hline & $\begin{array}{c}\text { cGAS } \\
{\left[g^{-1} \cdot \mathbf{g}^{-1}\right.} \\
\text { (This Study) }\end{array}$ & $\begin{array}{c}\text { AoFOx } \\
{\left[\mathbf{g} \cdot \mathbf{g}^{-1} \text { ] }\right.} \\
{[8]}\end{array}$ & $\begin{array}{c}\mathrm{rAae \text {UPO }} \\
{\left[\mathbf{g} \cdot \mathbf{g}^{-1} \text { ] }\right.} \\
{[8]}\end{array}$ \\
\hline simple $E$ factor & 938 & 4300 & 18,500 \\
complete $E$ factor & 37,835 & 106,100 & 209,000 \\
$E^{+}$factor & 62,033 & 157,800 & 566,800 \\
\hline
\end{tabular}

However, since the simple $E$ factor does not consider the consumption of solvents and water, which leave the process contaminated and therefore have to be processed in an energy-intensive manner, the complete $E$ factor should rather be considered, which is $37,835 \mathrm{~g}$ waste per $\mathrm{g}$ cGAS. In comparison, for the expression and purification of the peroxygenases $\mathrm{r} A a e \mathrm{UPO}$ in Pichia pastoris, the complete $E$ factor was 209,000 g waste per g enzyme [8]. For the production of the formate oxidase AoFOx with E. coli at lab scale the complete $E$ factor was 106,100 $\mathrm{g}$ waste per $\mathrm{g}$ enzyme [8]. Both values were higher, probably because of the low enzyme amount synthesized during these expressions, which were estimated to be $8 \mathrm{mg} \cdot \mathrm{g}_{\mathrm{CDW}}{ }^{-1}$ for the $A o \mathrm{FOx}$ and $1 \mathrm{mg} \cdot \mathrm{g}_{\mathrm{CDW}}{ }^{-1}$ for the $\mathrm{rAaeUPO}$, respectively. The $E^{+}$factor, which additionally considers the energy consumption during the production of the enzyme, is $62,033 \mathrm{~g}$ waste per $\mathrm{g}$ purified cGAS.

Considering the actual contribution of the biocatalysts to the $E$ factor of a product synthesis depends on many parameters. Next to the amount of chemicals and water that are consumed for the product synthesis (Figure 1), the catalyst utilization (gram product per gram enzyme) is of significant importance. As already mentioned, $250 \mathrm{~g}$ cGAMP can be synthesized with $10 \mathrm{~g}$ cGAS, which corresponds to $25 \mathrm{~g}$ product per $\mathrm{g}$ biocatalyst. The contribution of the biocatalyst to the $E$ factor of the product synthesis could be decreased by enzyme immobilization that can, on the one hand, increase enzyme stability and, on the other hand, allow its reutilization. For example, co-immobilization of two enzymes, L-alanine dehydrogenase from Bacillus subtilis and formate dehydrogenase from Candida boidinii, enabled their use for 5 consecutive batch cycles [25]. Another example is the type A feruloyl esterase from Aspergillus niger, which exhibited a 32-fold thermal stability after immobilization resulting in a 73-fold higher space-time yield and high catalyst utilization [26]. Even though, immobilization might be accompanied by a decrease of enzyme activity, it demonstrates a good starting point for further process intensification with regard to environmental efficiency.

For chemical processes in the pharmaceutical industry, the $E$ factor is typically estimated between 25 and $100 \mathrm{~kg}$ waste per $\mathrm{kg}$ product [27]. The $E$ factors of some bioprocesses are exactly in this range [28]. For example, the enzyme-catalyzed synthesis of sitagliptin has an $E$ factor of 26 [2]. Even less developed enzymatic syntheses have reasonable $E$ factors, such as the enzymatic synthesis of antiviral drug vidarabine with an $E$ factor of 423 [29]. However, typically only the reaction step is considered for these calculations. Nevertheless, as elaborated here, the enzyme production has a significant impact on the economic and ecological assessment of bioprocesses and should be taken into account. 


\section{Materials and Methods}

\subsection{Recombinant Expression}

The expression strain E. coli BL21 (DE3) pLysS pET28a-thscGAS was spread on an LB $\left(10 \mathrm{~g} \cdot \mathrm{L}^{-1}\right.$ tryptone, $5 \mathrm{~g} \cdot \mathrm{L}^{-1}$ yeast extract, $5 \mathrm{~g} \cdot \mathrm{L}^{-1} \mathrm{NaCl}$ ) agar plate containing $50 \mathrm{mg} \cdot \mathrm{L}^{-1}$ Kanamycin and $25 \mathrm{mg} \cdot \mathrm{L}^{-1} \mathrm{Chloramphenicol}$ and incubated overnight at $37^{\circ} \mathrm{C}$. The next day, a pre-culture of one colony was grown in $10 \mathrm{~mL} 2 \mathrm{xYT}\left(16 \mathrm{~g} \cdot \mathrm{L}^{-1}\right.$ tryptone, $10 \mathrm{~g} \cdot \mathrm{L}^{-1}$ yeast extract, $5 \mathrm{~g} \cdot \mathrm{L}^{-1} \mathrm{NaCl}$ ) medium with the same antibiotic concentration and incubated for $8 \mathrm{~h}$ at $37^{\circ} \mathrm{C}$ and $200 \mathrm{rpm}$. The main culture of $200 \mathrm{~mL} \mathrm{2xYT} \mathrm{medium} \mathrm{in} \mathrm{a} \mathrm{2-L} \mathrm{baffled}$ shaking flask was inoculated to an $\mathrm{OD}_{600}$ of 0.05 . It was incubated at $37^{\circ} \mathrm{C}$ and $200 \mathrm{rpm}$ until an $\mathrm{OD}_{600}$ of 1 . The expression was induced with an IPTG concentration of $0.5 \mathrm{mM}$. The main culture was incubated at $20^{\circ} \mathrm{C}$ for $11 \mathrm{~h}$. The cells were harvested by centrifugation (25 $\mathrm{min}, 4^{\circ} \mathrm{C}, 4700 \mathrm{rpm}$ ) and the cell pellet was stored at $-20^{\circ} \mathrm{C}$.

\subsection{Protein Purification}

Cell pellets with a total biomass of $865 \mathrm{mg}$ cell dry weight were resuspended in $20 \mathrm{~mL}$ lysis buffer (50 mM Tris- $\mathrm{HCl}, 300 \mathrm{mM} \mathrm{NaCl}, 40 \mathrm{mM}$ imidazole, $1 \mathrm{mM}$ TCEP, pH 8) and disrupted by five cycles of sonication for $30 \mathrm{~s}$. Insoluble cellular debris was removed by centrifugation $\left(20 \mathrm{~min}, 4^{\circ} \mathrm{C}, 19,000 \mathrm{rpm}\right)$. The centrifugate was filtrated $(0.2 \mu \mathrm{m})$ and loaded onto a $1 \mathrm{~mL}$ HisTrap ${ }^{\mathrm{TM}} \mathrm{FF}$ crude column (GE Healthcare, Solingen, Germany), which was previously equilibrated with 5 column volumes $(\mathrm{CV})$ of ultrapure water and $10 \mathrm{CV}$ of lysis buffer. The column was washed with $10 \mathrm{CV}$ lysis buffer. The purified enzyme was eluted into fractions in $6 \mathrm{CV}$ elution buffer $(20 \mathrm{mM}$ Tris- $\mathrm{HCl}, 150 \mathrm{mM} \mathrm{NaCl}, 300 \mathrm{mM}$ imidazole, $\mathrm{pH}$ 7.4). Protein containing fractions were identified by Bradford assay and combined. By using a PD-10 column (GE Healthcare, Solingen, Germany), which was previously equilibrated with $25 \mathrm{~mL}$ ultrapure water and $25 \mathrm{~mL}$ activity buffer $(40 \mathrm{mM}$ HEPES, $10 \mathrm{mM} \mathrm{MgCl} 2 \cdot 6 \mathrm{H}_{2} \mathrm{O}, \mathrm{pH} 7.2$ ), the enzyme was subsequently desalted. The final concentration was determined with a Bradford assay in the last step.

\section{Conclusions}

In this study, energy, chemicals, and water consumption were determined for the heterologous expression and purification of a model enzyme and the $E$ factor was calculated. These values can be easily transferred to similar processes in order to estimate the contribution of biocatalyst synthesis to a bioprocess. Overall, we showed that the contribution of biocatalyst synthesis is significant and cannot be neglected in the ecological assessment of a bioprocess. By this approach, significant steps can be easily and quickly identified to reduce the $E$ factor. A more detailed consideration could be provided by a LCA. Even though this approach is much more extensive and complex, it provides more insight into the environmental impacts including the use of mass and energy as well as the contribution to environment, health and safety. However, current databases contain only minor data for bioprocesses. For example, simple standard chemicals such as yeast extract, trypton, and buffer salts cannot be provided through these databases. Furthermore, models of unit operations of bioprocesses and impacts of bioprocesses on environment, health and safety are required. In future, effort will therefore certainly be done to establish ecological assessment methods in order to enable a standardized holistic sustainability evaluation of bioprocesses.

Supplementary Materials: Table S1: Chemicals required for pre-cultivation and expression of the enzyme, Table S2: Chemicals required for the purification of $10 \mathrm{~g}$ enzyme.

Author Contributions: Conceptualization, K.R. and S.L.; methodology, M.B., K.R. and S.L.; formal analysis, M.B. and K.R.; investigation, M.B.; resources, S.L.; data curation, M.B. and K.R.; visualization, M.B. and K.R.; supervision, K.R. and S.L.; project administration, K.R. and S.L. All authors have read and agreed to the published version of the manuscript. 
Funding: This research was supported by the CLIB-Competence Center Biotechnology (CKB) funded by the European Regional Development Fund (EFRE) and the North-Rhine Westphalian Ministry of Economic Affairs, Innovation, Digitalisation and Energy (MWIDE). (Grant number: EFRE-0300098).

Institutional Review Board Statement: Not applicable

Informed Consent Statement: Not applicable.

Data Availability Statement: Data is contained within the article or supplementary material.

Conflicts of Interest: The authors declare no conflict of interest.

\section{Appendix A}

Equation (A1) gives the calculation for the process mass intensity (PMI). The total mass ( $\mathrm{m}$ ) of materials used is divided by the amount of product obtained.

$$
P M I=\frac{\sum m(\text { materials })}{m(\text { product })}\left[\frac{k g}{k g}\right]
$$

Equation (A2) gives the calculation for the $E$ factor. The mass $(\mathrm{m})$ of product produced is subtracted from the total mass of materials consumed and divided by the mass of product produced. The simple $E$ factor includes only chemicals consumed, whereas the complete $E$ factor also includes water consumed.

$$
E=\frac{\sum m(\text { materials })-m(\text { product })}{m(\text { product })}\left[\frac{\mathrm{kg}}{\mathrm{kg}}\right]
$$

Equation (A3) gives the calculation for the $E^{+}$factor. The mass (m) of product produced is subtracted from the total mass of materials consumed and divided by the amount of product produced. In addition, the $\mathrm{CO}_{2}$ emission is calculated from the electrical power (W) and the carbon intensity (CI), divided by the product mass and summed [8].

$$
E^{+}=\frac{\sum m(\text { waste })}{m(\text { product })}\left[\frac{k g}{k g}\right]+\frac{W \times C I}{m(\text { product })}\left[\frac{k W h \times \frac{k g\left(\mathrm{CO}_{2}\right)}{k W h}}{k g}\right]
$$

\section{Appendix B}

\begin{tabular}{|c|c|c|c|c|c|c|}
\hline & Unit & $\begin{array}{l}\text { Plating } \\
\text { E. coli }\end{array}$ & Pre-Culture & $\begin{array}{c}\text { Inoculum } \\
\text { Pre-Fermenter }\end{array}$ & Pre-Fermenter & $\begin{array}{c}\text { Main- } \\
\text { Fermenter }\end{array}$ \\
\hline Water & $\mathrm{L}$ & 0.05 & 0.05 & 2.95 & 27 & 245 \\
\hline Tryptone & $\mathrm{g}$ & 0.5 & 0.8 & 47.2 & 432 & 3920 \\
\hline Yeast Extract & $\mathrm{g}$ & 0.25 & 0.5 & 29.5 & 270 & 2450 \\
\hline $\mathrm{NaCl}$ & $\begin{array}{l}8 \\
\mathrm{~g}\end{array}$ & 0.25 & 0.25 & 14.75 & 135 & 1225 \\
\hline Agar & $\begin{array}{l}0 \\
\mathrm{~g}\end{array}$ & 0.75 & - & - & - & - \\
\hline IPTG & $\mathrm{g}$ & - & - & - & - & 29.2 \\
\hline Chloramphenicol & $\mathrm{mg}$ & 0.6 & 0.6 & 35.4 & 324 & 2940 \\
\hline Kanamycin & $\mathrm{mg}$ & 2.5 & 2.5 & 147.5 & 1350 & 12,250 \\
\hline Energy & $\mathrm{kWh}$ & 13.68 & 2 & 14.8 & 100.6 & 412.2 \\
\hline
\end{tabular}

Table A1. Detailed list of all chemicals and energy quantities required during seed-train and enzyme expression. 
Table A2. Detailed list of all chemicals and energy quantities required during enzyme purification.

\begin{tabular}{|c|c|c|c|c|c|c|}
\hline & Unit & $\begin{array}{c}\text { Cell } \\
\text { Harvesting }\end{array}$ & $\begin{array}{c}\text { Cell } \\
\text { Disruption }\end{array}$ & Centrifugation & $\begin{array}{c}\text { Affinity } \\
\text { Chromatography }\end{array}$ & $\begin{array}{c}\text { Buffer } \\
\text { Exchange }\end{array}$ \\
\hline Water & $\mathrm{L}$ & - & 5 & - & 23 & 63 \\
\hline EtOH & $\mathrm{L}$ & - & - & - & 0.5 & 3.2 \\
\hline Tris-HCl & $\mathrm{g}$ & - & 39.4 & - & 96.2 & - \\
\hline $\mathrm{NaCl}$ & $\mathrm{g}$ & - & 87.65 & - & 223.6 & - \\
\hline Imidazole & g & - & 13.65 & - & 139.7 & - \\
\hline TCEP & g & - & 1.435 & - & - & - \\
\hline HEPES & g & - & - & - & - & 173.5 \\
\hline $\begin{array}{l}\mathrm{MgCl}_{2} \cdot 6 \\
\mathrm{H}_{2} \mathrm{O}\end{array}$ & $\mathrm{g}$ & - & - & - & - & 37 \\
\hline Energy & kWh & 17.55 & 26.03 & 4.6 & 8.8 & 3.2 \\
\hline
\end{tabular}

\section{References}

1. Straathof, A.J.J.; Panke, S.; Schmid, A. The Production of Fine Chemicals by Biotransformations. Curr. Opin. Biotechnol. 2002, 13, 548-556. [CrossRef]

2. Savile, C.K.; Janey, J.M.; Mundorff, E.C.; Moore, J.C.; Tam, S.; Jarvis, W.R.; Colbeck, J.C.; Krebber, A.; Fleitz, F.J.; Brands, J.; et al. Biocatalytic Asymmetric Synthesis of Chiral Amines from Ketones Applied to Sitagliptin Manufacture. Science 2010, 329, 305-309. [CrossRef] [PubMed]

3. EN ISO. ISO 14044: Environmental Management_Life Cycle Assessment_Requirements and Guidelines; International Organisation for Standardisation: Geneva, Switzerland, 2006.

4. Ni, Y.; Holtmann, D.; Hollmann, F. How Green Is Biocatalysis? To Calculate Is to Know. ChemCatChem 2014, 6, 930-943. [CrossRef]

5. Jiménez-González, C.; Woodley, J.M. Bioprocesses: Modeling Needs for Process Evaluation and Sustainability Assessment. Comput. Chem. Eng. 2010, 34, 1009-1017. [CrossRef]

6. Jimenez-Gonzalez, C.; Ponder, C.S.; Broxterman, Q.B.; Manley, J.B. Using the Right Green Yardstick: Why Process Mass Intensity Is Used in the Pharmaceutical Industry to Drive More Sustainable Processes. Org. Process Res. Dev. 2011, 15, 912-917. [CrossRef]

7. Sheldon, R.A. The E Factor: Fifteen Years On. Green Chem. 2007, 9, 1273-1283. [CrossRef]

8. Tieves, F.; Tonin, F.; Fernández-Fueyo, E.; Robbins, J.M.; Bommarius, B.; Bommarius, A.S.; Alcalde, M.; Hollmann, F. Energising the E-Factor: The E + -Factor. Tetrahedron 2019, 75, 1311-1314. [CrossRef]

9. Henderson, R.K.; Jiménez-González, C.; Preston, C.; Constable, D.J.C.; Woodley, J.M. EHS \& LCA Assessment for 7-ACA Synthesis A Case Study for Comparing Biocatalytic and Chemical Synthesis. Ind. Biotechnol. 2008, 4, 180-192.

10. Ma, S.K.; Gruber, J.; Davis, C.; Newman, L.; Gray, D.; Wang, A.; Grate, J.; Huisman, G.W.; Sheldon, R.A. A Green-by-Design Biocatalytic Process for Atorvastatin Intermediate. Green Chem. 2010, 12, 81-86. [CrossRef]

11. Sun, L.; Wu, J.; Du, F.; Chen, X.; Chen, Z.J. Cyclic GMP-AMP Synthase Is a Cytosolic DNA Sensor That Activates the Type I Interferon Pathway. Science 2013, 339, 786-791. [CrossRef]

12. Ablasser, A.; Goldeck, M.; Cavlar, T.; Deimling, T.; Witte, G.; Röhl, I.; Hopfner, K.-P.; Ludwig, J.; Hornung, V. CGAS Produces a 2'-5'-Linked Cyclic Dinucleotide Second Messenger That Activates STING. Nature 2013, 498, 380-384. [CrossRef] [PubMed]

13. Corrales, L.; Glickman, L.H.; McWhirter, S.M.; Kanne, D.B.; Sivick, K.E.; Katibah, G.E.; Woo, S.-R.; Lemmens, E.; Banda, T.; Leong, J.J.; et al. Direct Activation of STING in the Tumor Microenvironment Leads to Potent and Systemic Tumor Regression and Immunity. Cell Rep. 2015, 11, 1018-1030. [CrossRef] [PubMed]

14. Dubensky, T.W.; Kanne, D.B.; Leong, M.L. Rationale, Progress and Development of Vaccines Utilizing STING-Activating Cyclic Dinucleotide Adjuvants. Ther. Adv. Vaccines 2013, 1, 131-143. [CrossRef] [PubMed]

15. Sheldon, R.A.; Brady, D.; Bode, M.L. The Hitchhiker's Guide to Biocatalysis: Recent Advances in the Use of Enzymes in Organic Synthesis. Chem. Sci. 2020, 11, 2587-2605. [CrossRef]

16. Farid, S.S.; Baron, M.; Stamatis, C.; Nie, W.; Coffman, J. Benchmarking Biopharmaceutical Process Development and Manufacturing Cost Contributions to R\&D. MAbs 2020, 12, 1754999. [CrossRef]

17. Rosenthal, K.; Becker, M.; Rolf, J.; Siedentop, R.; Hillen, M.; Nett, M.; Lütz, S. Catalytic Promiscuity of CGAS: A Facile Enzymatic Synthesis of 2'-3'-Linked Cyclic Dinucleotides. ChemBioChem 2020, 21, 3225-3228. [CrossRef]

18. Novotná, B.; Vaneková, L.; Zavřel, M.; Buděšínský, M.; Dejmek, M.; Smola, M.; Gutten, O.; Tehrani, Z.A.; Pimková Polidarová, M.; Brázdová, A.; et al. Enzymatic Preparation of $2^{\prime}-5^{\prime}, 3^{\prime}-5^{\prime}$-Cyclic Dinucleotides, Their Binding Properties to Stimulator of Interferon Genes Adaptor Protein, and Structure/Activity Correlations. J. Med. Chem. 2019, 62, 10676-10690. [CrossRef]

19. Waegeman, H.; De Lausnay, S.; Beauprez, J.; Maertens, J.; De Mey, M.; Soetaert, W. Increasing Recombinant Protein Production in Escherichia Coli K12 through Metabolic Engineering. New Biotechnol. 2013, 30, 255-261. [CrossRef]

20. Restaino, O.F.; Borzacchiello, M.G.; Scognamiglio, I.; Fedele, L.; Alfano, A.; Porzio, E.; Manco, G.; De Rosa, M.; Schiraldi, C. High Yield Production and Purification of Two Recombinant Thermostable Phosphotriesterase-like Lactonases from Sulfolobus Acidocaldarius and Sulfolobus Solfataricus Useful as Bioremediation Tools and Bioscavengers. BMC Biotechnol. 2018, 18, 1-15. [CrossRef]

21. Rosano, G.L.; Morales, E.S.; Ceccarelli, E.A. New Tools for Recombinant Protein Production in Escherichia Coli: A 5-Year Update. Protein Sci. 2019, 28, 1412-1422. [CrossRef] 
22. Hoffman, B.J.; Broadwater, J.A.; Johnson, P.; Harper, J.; Fox, B.G.; Kenealy, W.R. Lactose Fed-Batch Overexpression of Recombinant Metalloproteins in Escherichia Coli BL21(DE3): Process Control Yielding High Levels of Metal-Incorporated, Soluble Protein. Protein Expr. Purif. 1995, 6, 646-654. [CrossRef] [PubMed]

23. Tufvesson, P.; Lima-Ramos, J.; Nordblad, M.; Woodley, J.M. Guidelines and Cost Analysis for Catalyst Production in Biocatalytic Processes. Org. Process Res. Dev. 2011, 15, 266-274. [CrossRef]

24. Icha, P.; Kuhs, G. Climate Change: Entwicklung Der Spezifischen Kohlendioxid-Emissionen Des Deutschen Strommix in Den Jahren 1990-2019; Umweltbundesamt: Dessau-Roßlau, Germany, 2020.

25. Velasco-Lozano, S.; da Silva, E.S.; Llop, J.; López-Gallego, F. Sustainable and Continuous Synthesis of Enantiopure L-Amino Acids by Using a Versatile Immobilised Multienzyme System. ChemBioChem 2018, 19, 395-403. [CrossRef] [PubMed]

26. Grajales-Hernández, D.; Armendáriz-Ruiz, M.; Velasco-Lozano, S.; López-Gallego, F.; Mateos-Díaz, J.C. Chitosan-Based CLEAs from Aspergillus Niger Type A Feruloyl Esterase: High-Productivity Biocatalyst for Alkyl Ferulate Synthesis. Appl. Microbiol. Biotechnol. 2020, 104, 10033-10045. [CrossRef]

27. Sheldon, R.A. E Factors, Green Chemistry and Catalysis: An Odyssey. Chem. Commun. 2008, 29, 3352-3365. [CrossRef]

28. Rosenthal, K.; Lütz, S. Recent Developments and Challenges of Biocatalytic Processes in the Pharmaceutical Industry. Curr. Opin. Green Sustain. Chem. 2018, 11, 58-64. [CrossRef]

29. Serra, I.; Daly, S.; Alcantara, A.R.; Bianchi, D.; Terreni, M.; Ubiali, D. Redesigning the Synthesis of Vidarabine via a Multienzymatic Reaction Catalyzed by Immobilized Nucleoside Phosphorylases. RSC Adv. 2015, 5, 23569-23577. [CrossRef] 